\title{
Application of Geographical Information System (GIS) for Siting and Management of Solid Waste Disposal in Akure, Nigeria
}

\author{
${ }^{1}$ Michael Ajide Oyinloye* and ${ }^{2}$ Julius Olubumi Fasakin \\ Department of Urban and Regional Planning, School of Environmental Technology, \\ Federal University of Technology, Akure, Nigeria
}

\begin{abstract}
Locating a landfill site in cities of Developing nations have been recognized as a significant physical planning problem and is receiving much attention from researchers in planning sector. A suitable disposal site must have environmental safety criteria and attributes that enable the wastes to be isolated at no risk to people or the environment. Criteria for site selection include; natural physical characteristics, socio-economic, ecological and landuse factors. Different tools and techniques have been developed for solid waste disposal site selection in Developing Countries. This paper examines the selection of waste disposal sites using Geographical Information System in Akure, Nigeria. Landsat Enhanced Thematic Mapper plus $\left(E^{2 T M^{+}}\right) 2002$ and Shuttle Radar Topographic Mission (SRTM) 2011 were used to map the most suitable site for waste disposal in Akure. The result indicates that sites were found within the study area. The most suitable sites in the study area are located at $750 \mathrm{~m}$ to surface water and $300 \mathrm{~m}$ to major and minor roads, which ensure that economic costs of implementation are mutual. The selected areas have slopes less than $12 \%$, with infrastructural advantage and minimizing environmental impacts. The study proposes acceptable landfill sites for solid waste disposal in the city.
\end{abstract}

Key words: Waste disposal, GIS, landfill, Site selection, Landsat, Shuttle Radar

\section{Introduction}

The increasing level of municipal solid waste is, nowadays, a serious problem in urban area of the world. A high population growth rate and increasing per capita income have resulted in the generation of enormous municipal solid waste, posing a serious threat to environmental quality and human health. This is particularly notable in the Developing Countries where large quantities of wastes are dumped haphazardly, thereby putting pressure on scarce land and water resources. At the same time, this adversely affects the health of human beings, especially poor persons who lives close to such sites (Chakrabarti, 2003). Unsustainable waste disposal is a sensitive issue with serious environmental problems all over the world. The prevailing situation of dumping of wastes without proper inspection and separation leads to environmental pollution causing a tremendous growth in health-related problems. "Domestic, industrial and other wastes, either of low or medium level causes environmental pollution perennially for mankind." (Senthil , 2002).

Availability of land for disposal of municipal waste via land filling is getting scarce nowadays. Landfills have created various problems such as ground water contamination and uncontrolled emission of gases causing explosions. These problems result into evasion to landfill by the communities all over the world. Landfill siting becomes one of the problems confronting waste management planners due to site requirements for its operations. Besides, escalating environmental degradation and awareness, increasing costs, community and political opposition, increasing population densities and shortage of land availability. Public health also contributes to the difficulty of choosing suitable land for landfill (Sadek et al., 2001).

Therefore, in a landfill siting process, many factors are taken into consideration and carefully evaluated. Consequently, the most suitable sites must have minimum impacts on the environment, society and economy as well as conforming to the planning regulations. However, it is time consuming and tedious to implement such a complex procedure by using manual processing approaches (Kao et al, 1996). In addition, there are numerous data to process and sometimes the process might be repeated for several times for the best site chosen (Bayode, 2011).

During the last decades, it was difficult to do such studies taking a lot of time and efforts; but today it is easier by using GIS which is more suitable and functional in finding the best location with little limitations. GIS is one of the new technologies which have contributed a lot in a short time span to waste management. "The Geographic Information System (GIS) helps to manipulate data in the computer to simulate alternatives and to take the most effective decisions" (Yagoub, 1998).

GIS has very distinguishing and powerful functions that play an important role in decision- making and planning process. "The most distinguishing parts of a GIS are its functions for spatial analysis, i.e. operations that use spatial data to derive new geo- information. Spatial queries and process models play an important role in satisfying user needs. The combination of database, GIS software, rules, and reasoning mechanism 
(implemented as inference engine) leads to what is sometimes called a Spatial Decision Support System (SDSS) (Yagoub, 1998).

According to Bodhankar \& Chatterjee (1994), facility siting is also ecologically significant, as it has a large impact on the surrounding environment. For example, landfills have been known to contaminate drinking water wells, groundwater aquifers and nearby streams. Nagar \& Mizra (2002) also highlight that, the ecological effects of any site proposal must be considered, as a site could have the potential to release chemicals into nearby waterways and tributaries via ground leaching. The final barrier in facility siting is finding a location that would have the least impact on the environment (Basagaoglu et al., 1997).

Groundwater contamination could occur, if the water table is close to the surface.

Surface water contamination could occur as a result of runoff due to a steep sloping surface (Dikshit et al., 2001). These environmental factors are among many of the concerns that need to be considered in the site selection process (Kao \& Lin, 1996).

Landfill site selection has been a problem experienced not only in Nigeria but worldwide. However, over the years, several researchers have also discovered ways of particularly solving this problem by applying computer based techniques in the process of selecting suitable landfill sites. According to Gao et al, (2004), any decision making process that focuses on problems that are either dependent or influenced by geographical information is spatial decision making.

GIS as a decision support tool, simplifies the search for suitable sites for a particular purpose because of its capability of spatial feature extraction and classification. Site selection process is complex hence the need to integrate several decision support tools such as Expert Systems (ES), GIS and Multi-Criteria Evaluation (MCE) for an optimal selection (Kao et al., 1996).

Bloomfield (2000) highlights two extensions, which are particularly useful when conducting a facility siting analysis; namely, Spatial Analysis and Model Building. These tools can be used to construct both constraint and factor maps that can in turn be overlaid to find suitable regions on the final analysis. The region, which contains the most advantageous combination of the requirements, is then selected in the final decision for project development.

The objectives of this study are to:

1. specify important criteria to locating a landfill site in the study area.

2. identify and evaluate possible suitable locations of landfill in Akure.

3. highlight the effectiveness of GIS technology as a sitting tool in landfill site selection in the study area.

\section{The study area:}

Akure became the capital of Ondo State in 1976. It lies on latitude $7^{0} 5^{\prime}$ North of the Equator and longitude $5^{0} 15^{\prime}$ East of the Greenwich Meridian. It is about $370 \mathrm{~m}$ above the sea level, is situated within a 48kilometer radius to major towns in Ondo State, viz Ondo to the South, Owo to the East and Iju/Itaogbolu to the North. Easy access and geographical centrality of Akure to these towns have enhanced the growth prospects of the city (see figure $1 \mathrm{a}, 1 \mathrm{~b}$ and $1 \mathrm{c}$ ).

The population of Akure in 1963 was put 71, 006 and by 1999, the total population had risen to 239,124 (NPC, 1996).By the year 2006, the population had increased to 340,021 (NPC, 2006). The increase in annual growth of the population has been tied to the administrative role of the town and its long standing role as a centre of economic activities attracting a large spectrum of immigrants into it.

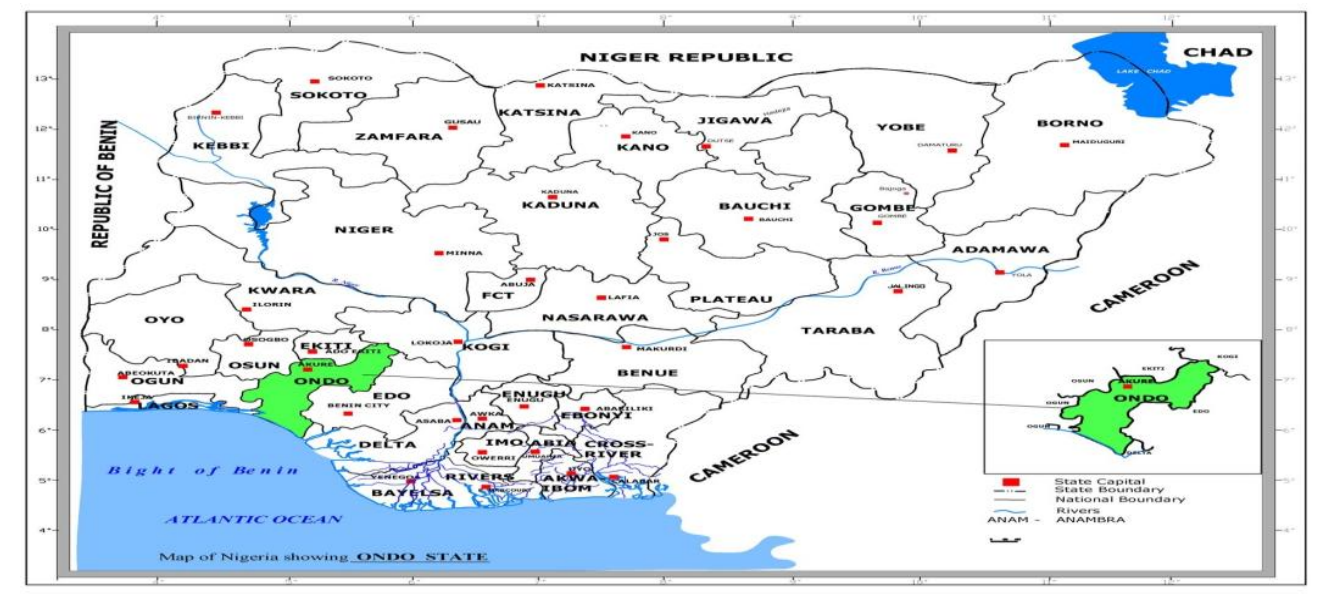

Figure 1a. Map of Nigeria showng Ondo State 


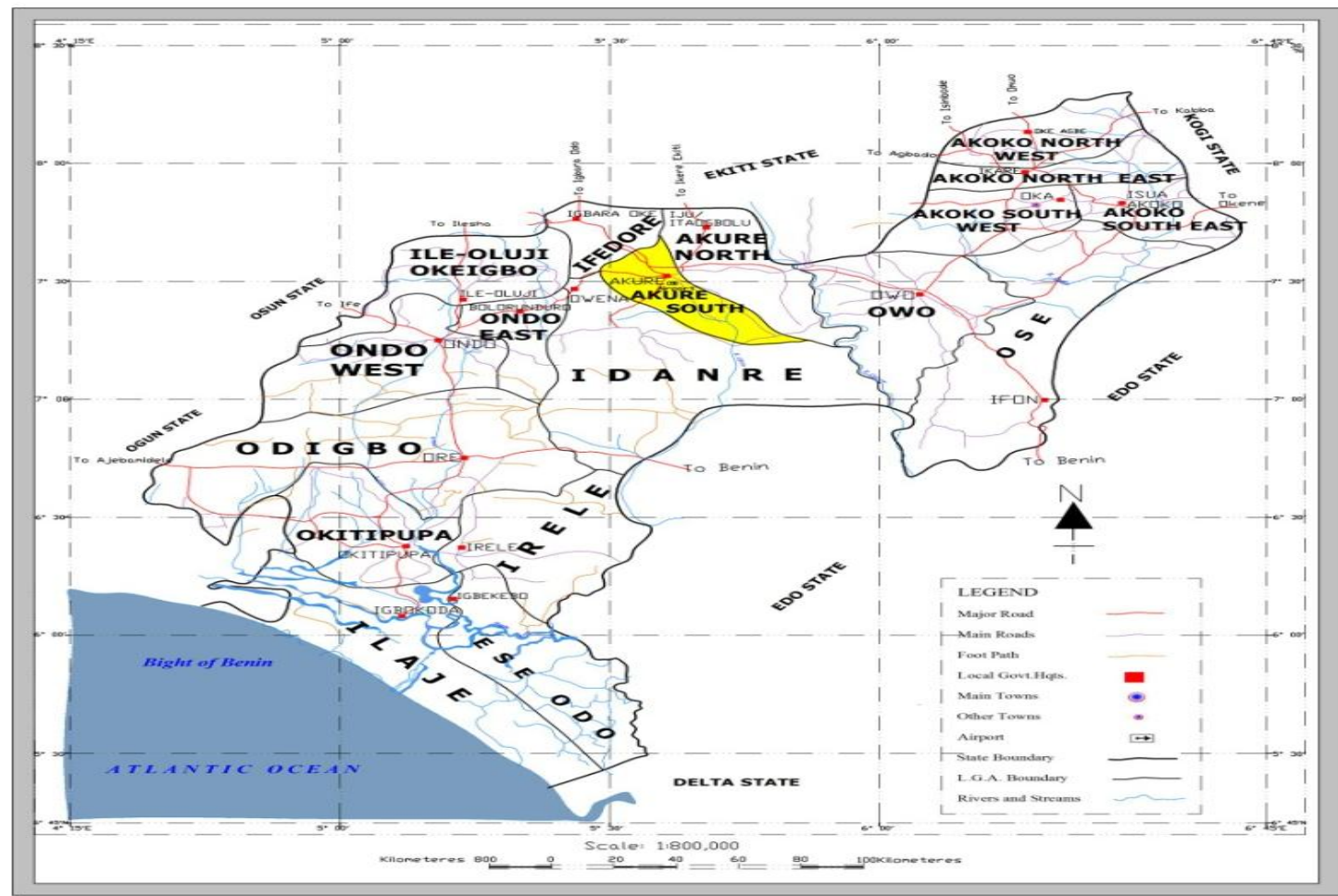

Figure 1b. Map of Ondo state showing Akure

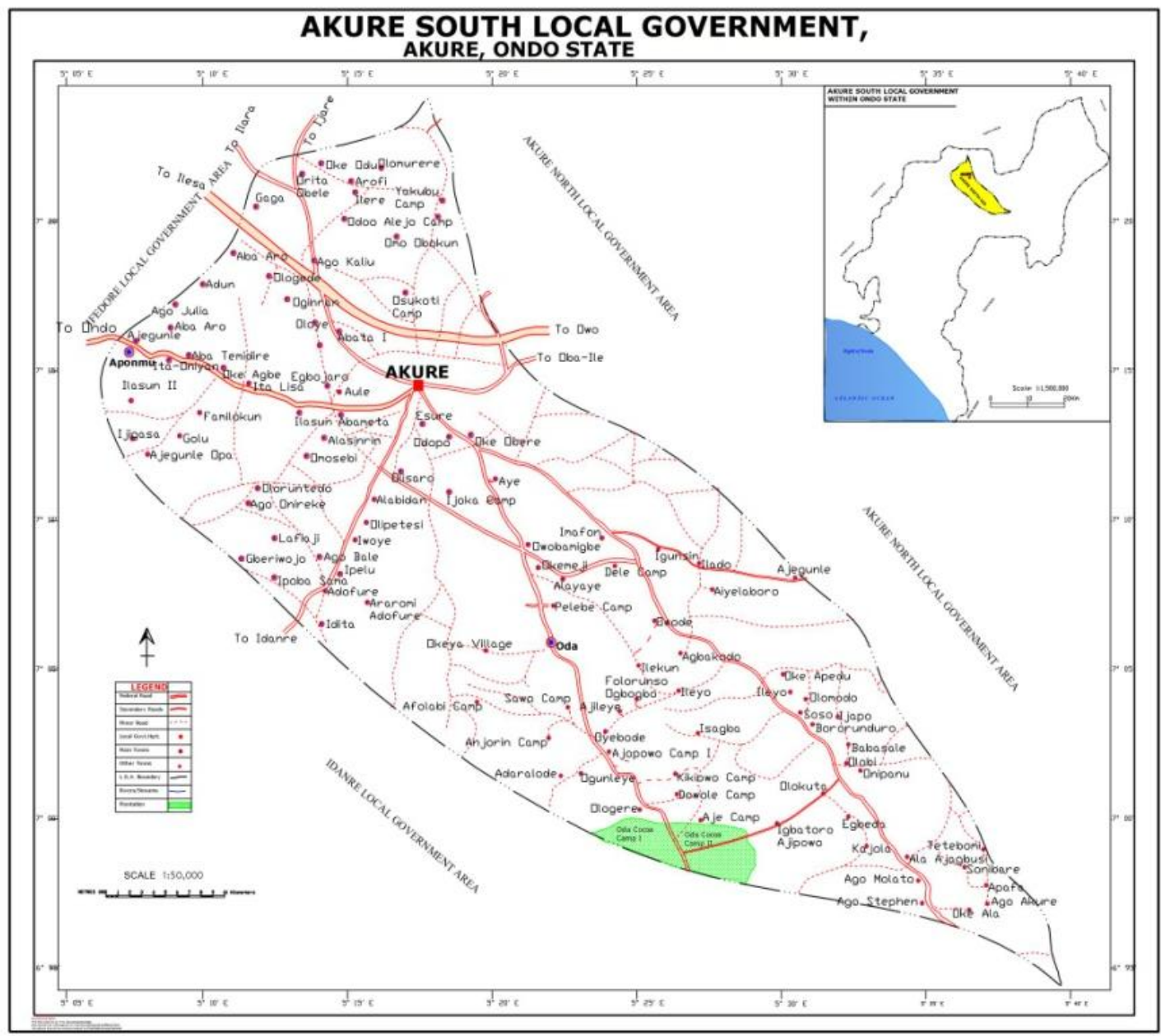

Figure 1c: Map of Ondo State showing Akure South Local Government 


\section{Data Acquisition and Method}

This study is interested in locating the most suitable area for waste disposal in Akure using the capabilities of GIS and remote sensing. To achieve this, two satellite imageries were used namely Landsat Enhanced Thematic Mapper plus (LANDSAT ETM ${ }^{+}$) of year 2002 and the Shuttle Radar Topographic Mission (SRTM), 2011. The Landsat satellite was used for slope analysis while Shuttle Reader Topographic Mission imagery was analysed to generate the Digital Elevation Model (DEM) of the study area.

(see figure 2)

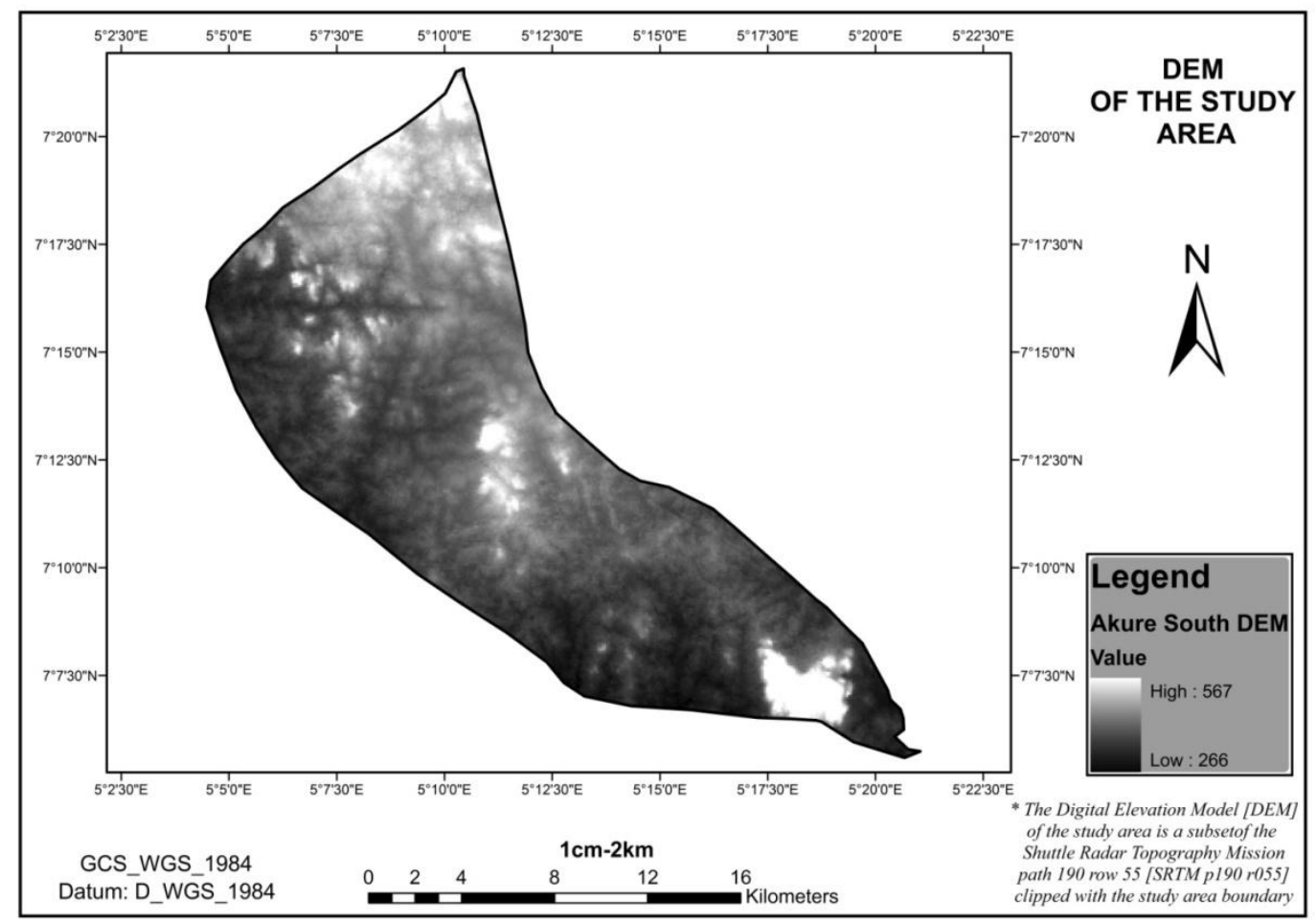

Figure 2: Digital Elevation Model (DEM) of the Study Area

\section{Constraint and Criteria}

The constraints for Landfill site in the study areas includes:

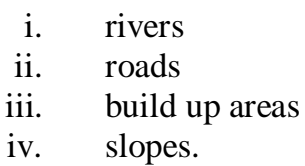

The above listed constraints were developed into maps to identify suitable and non suitable landfill sites in the study area. The criteria that must be satisfied for a suitable landfill site in Akure should be an area:

i. $\quad$ with slopes between $4-10 \%$

ii. $\quad 750 \mathrm{~m}$ distance from the nearest surface water

iii. Soil of low permeability e.g clay rich environment.

\section{Results and discussion}

The site selection model involves three steps: field survey findings, multi-criteria evaluation, and identification of the most suitable site. The field survey findings involve creating a study area map to input the rasterized data layers, then creating constraint maps and factor maps from the spatial data.

The second step involves multi-criteria evaluation, which is conducted by weighting the factor maps and combining them with the overlaid constraint map. The final step relates to finding the suitable sites using the information in the final suitability map.

A number of variables taken into consideration include land-use/land cover type, distance to streams, proximity to urban areas, and distance to transportation routes, slope, soil type and geology of the study area. 


\subsection{Factor Maps}

Factor maps illustrate suitability of a specified feature that ranges from not or least suitable areas to the most or highly suitable areas using a range of classes. The factor maps used for this study were slope, soil type and land use/land cover maps.

The land-use/land cover constraint map (Figure 3) represents different classes of land which are: the builtup areas, cultivated areas, natural vegetation, water bodies and rock outcrops.

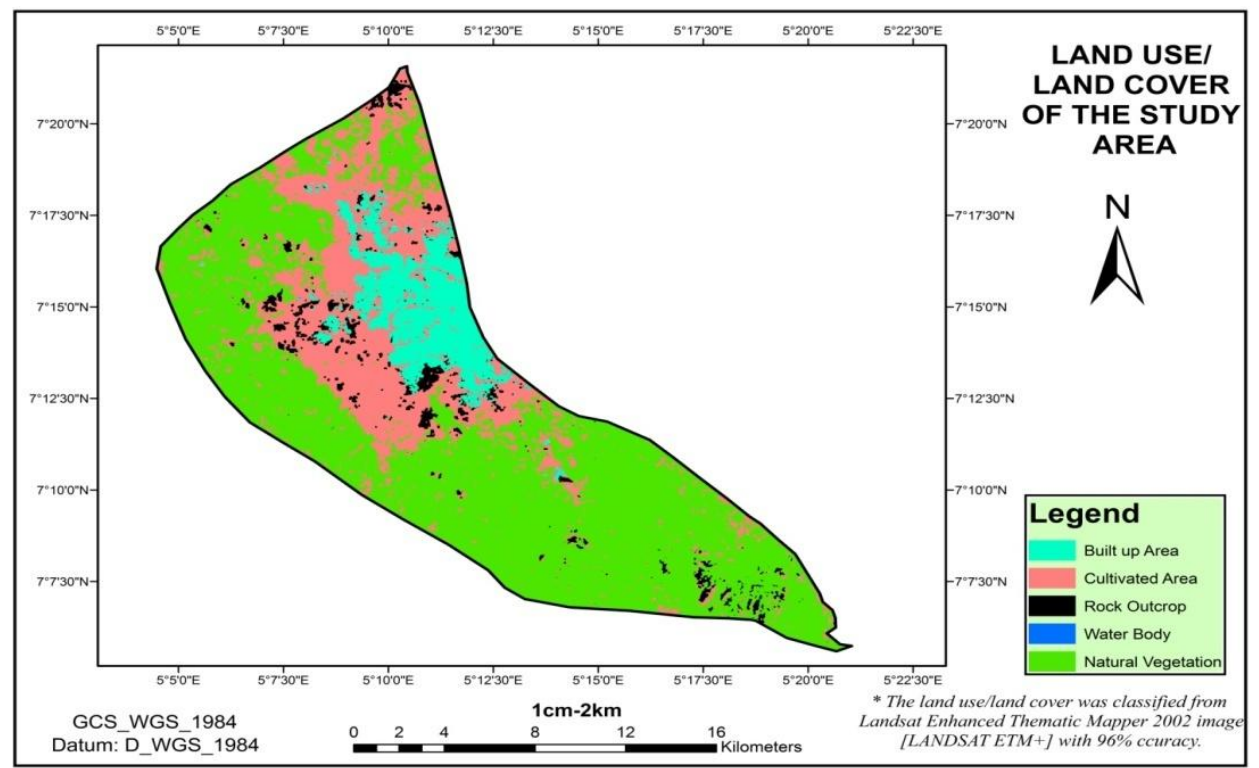

Figure 3: Factor Map Showing Landuse/ Landcover types in Akure

The map is re-classified into classes ranging from the least suitable to most suitable landfill sites. For example, bare land especially far-fetched unoccupied land from population centres, streams etc or places of natural vegetation are most suitable for landfill siting whereas cropland is fairly suitable because of destruction of economic crops and Livelihood of people, while the built-up areas are the restricted areas for landfill siting because of the health hazards, visual and nasal inconveniencies. Sites with potential for higher value uses such as agriculture, residential development and built-up areas are unsuitable as depicted in figure 4 below.

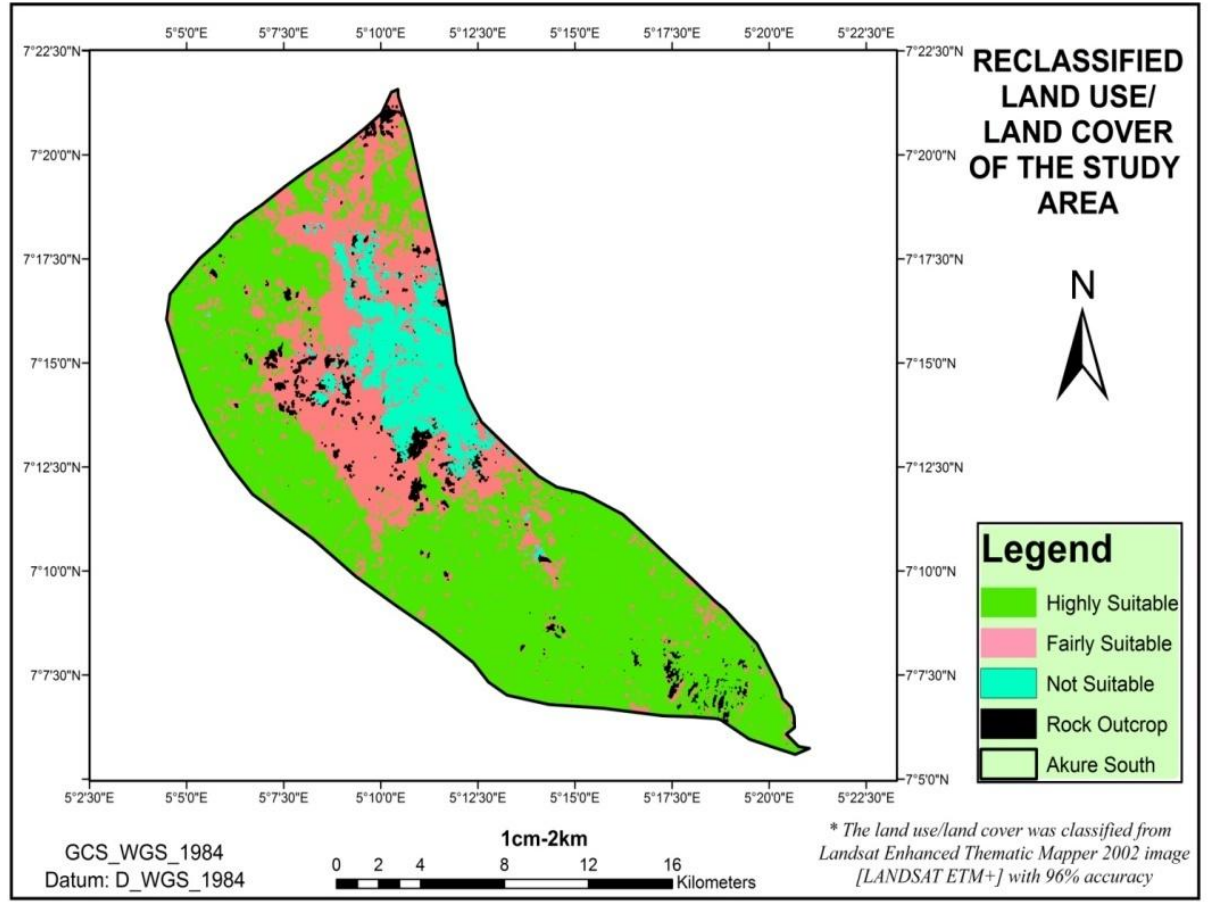

Figure 4: Reclassified land use/ land cover Map showing Suitability for Landfill Site Akure. 


\subsection{Slope}

A low slope is required to minimize erosion and water runoff. A lower slope also facilitates the construction of the site to be much easier and with lower costs (Atkinson et al., 1995). The slope of the study area is classified into five, ranging from $0 \%-63 \%$ shown in figure 5 below.

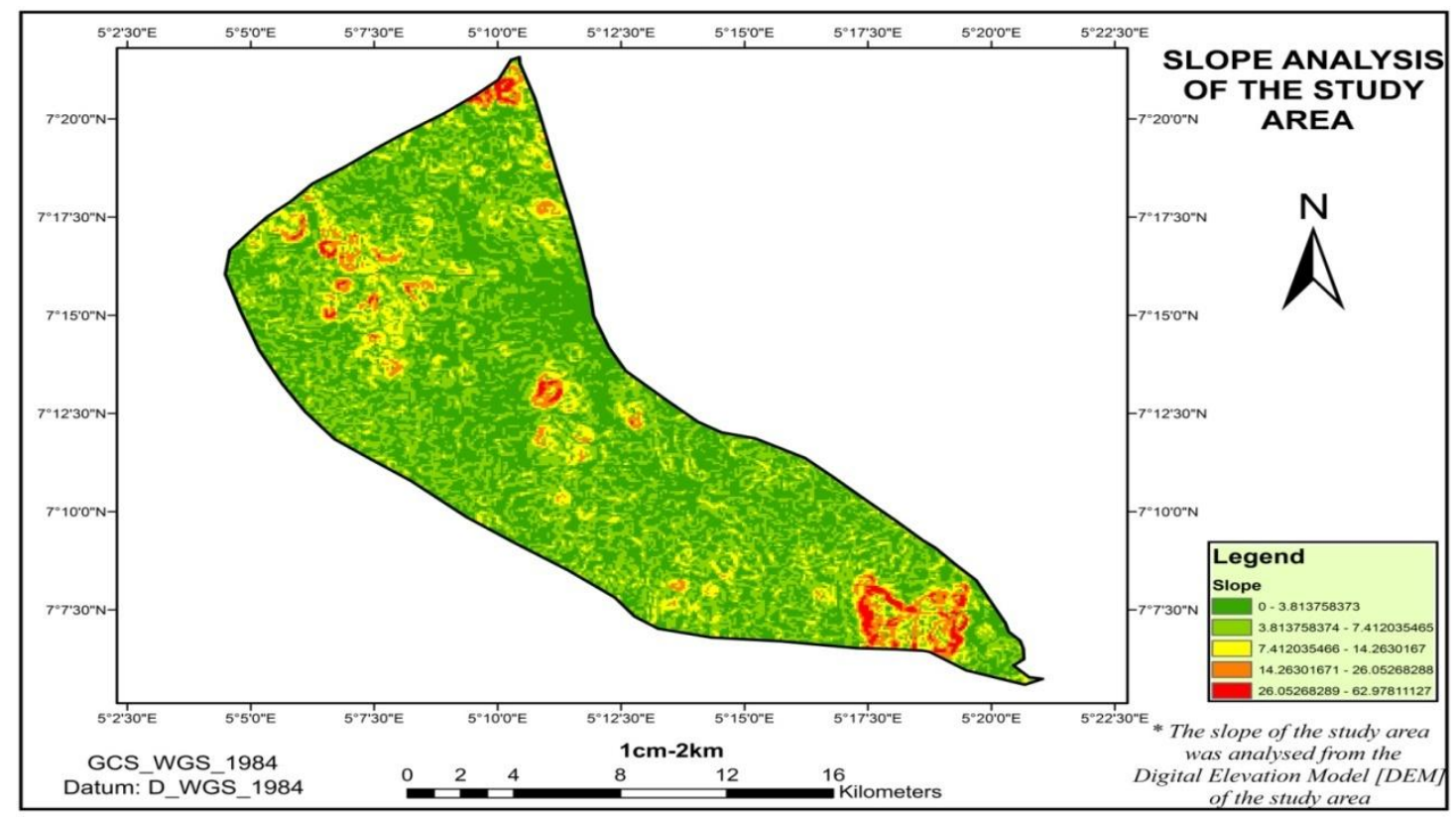

Figure 5: Slope Map of Akure.

The slope of the study area is re-classified into four, ranging from the least suitable site to most suitable site for landfill. The ideal slope chosen for the development of a landfill is between $0 \%-12 \%$. However, $4 \%-12 \%$ which is better for site for landfill in Akure is as shown in figure 6 below.

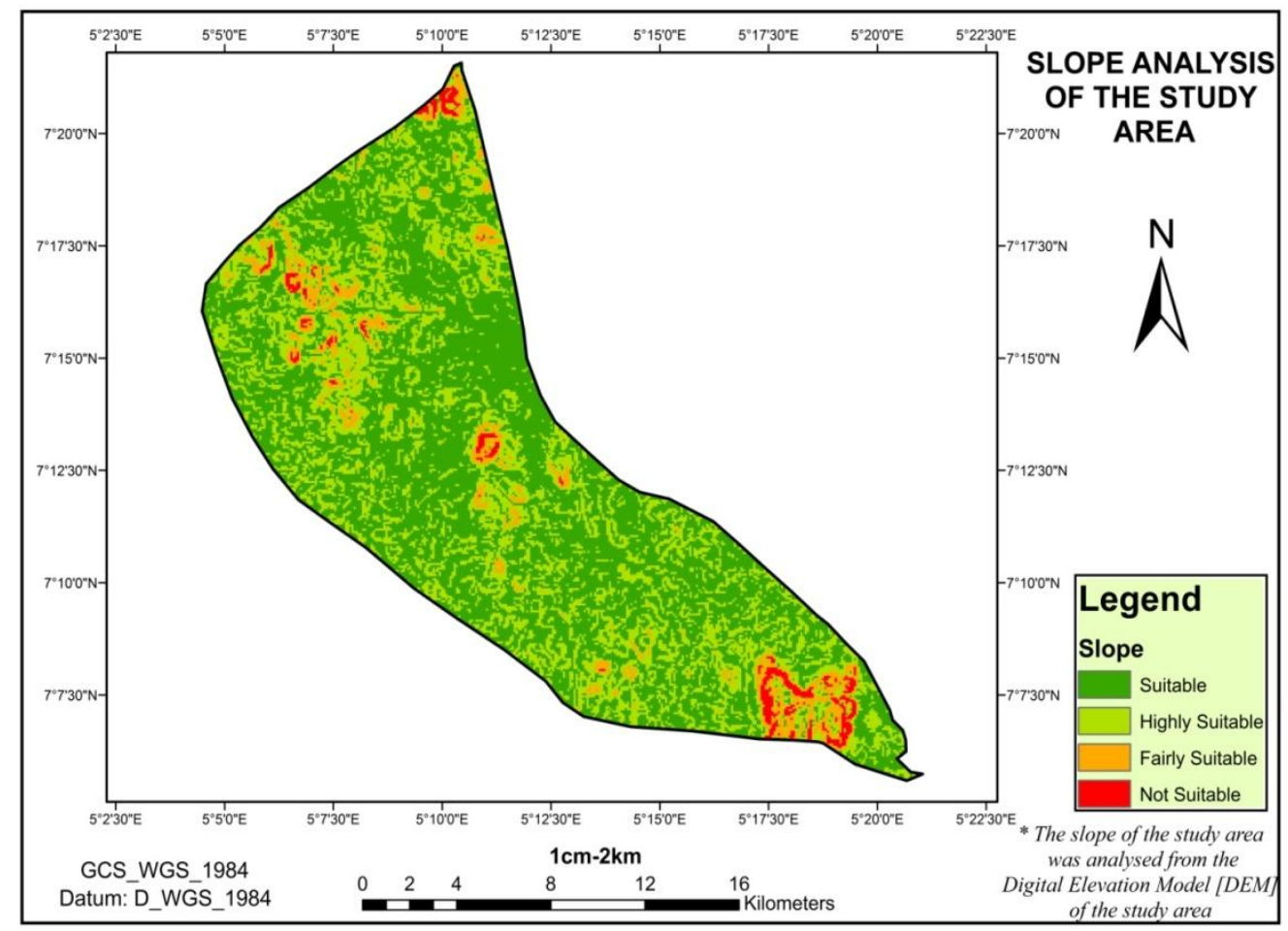

Figure 6: Reclassified slope Map showing Suitability for Landfill in Akure.

Triangulated Irregular Network (TIN) was also generated using the 3D Analysis of ArcMap (see figure 7).

The Digital Terrain Model DTM which shows the 3D view of the study area (high and low lands), was 
generated from the slope map using Global Mapper 11 software (see figure 8)

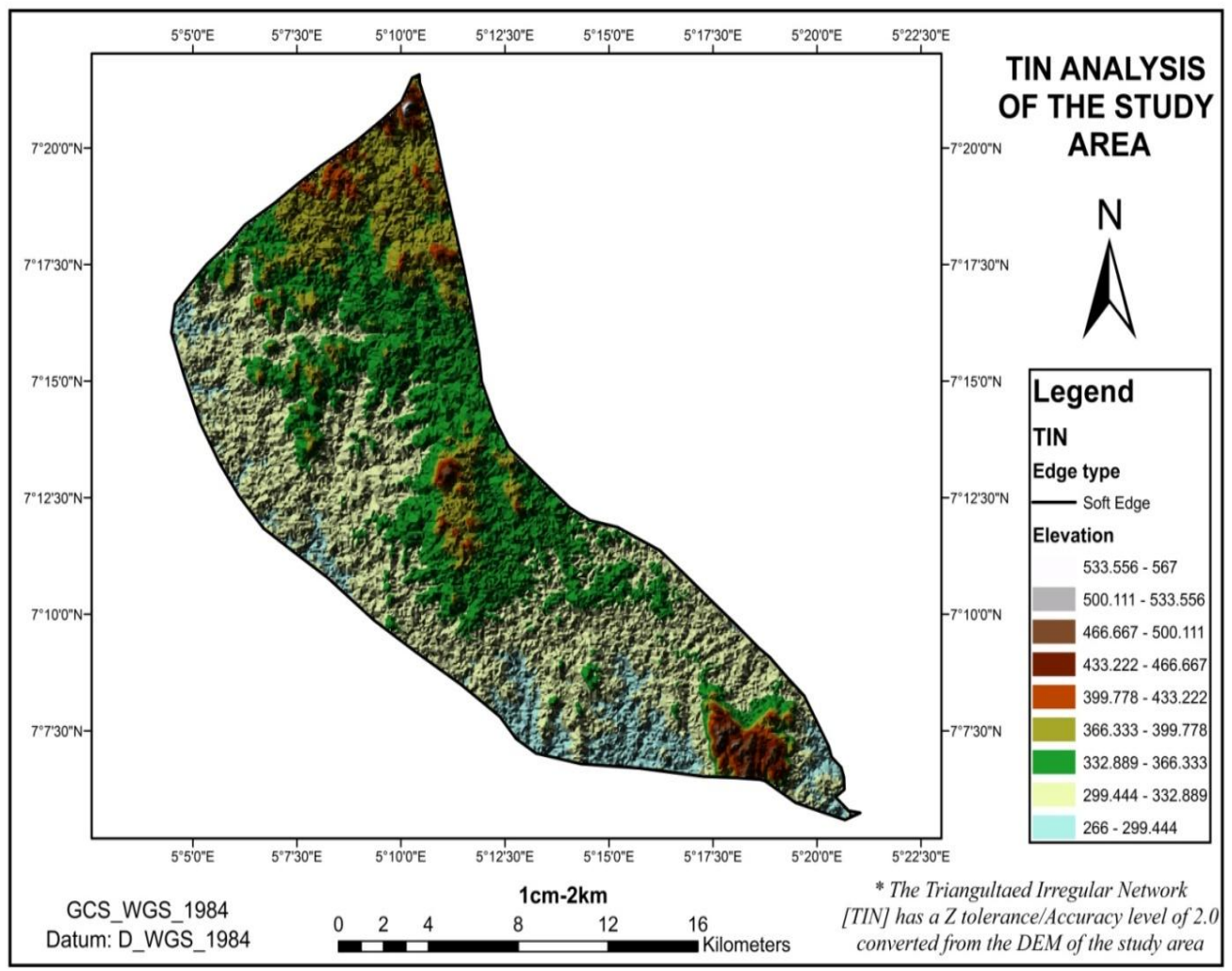

Figure 7: Triangulated Irregular Network (TIN) of Akure

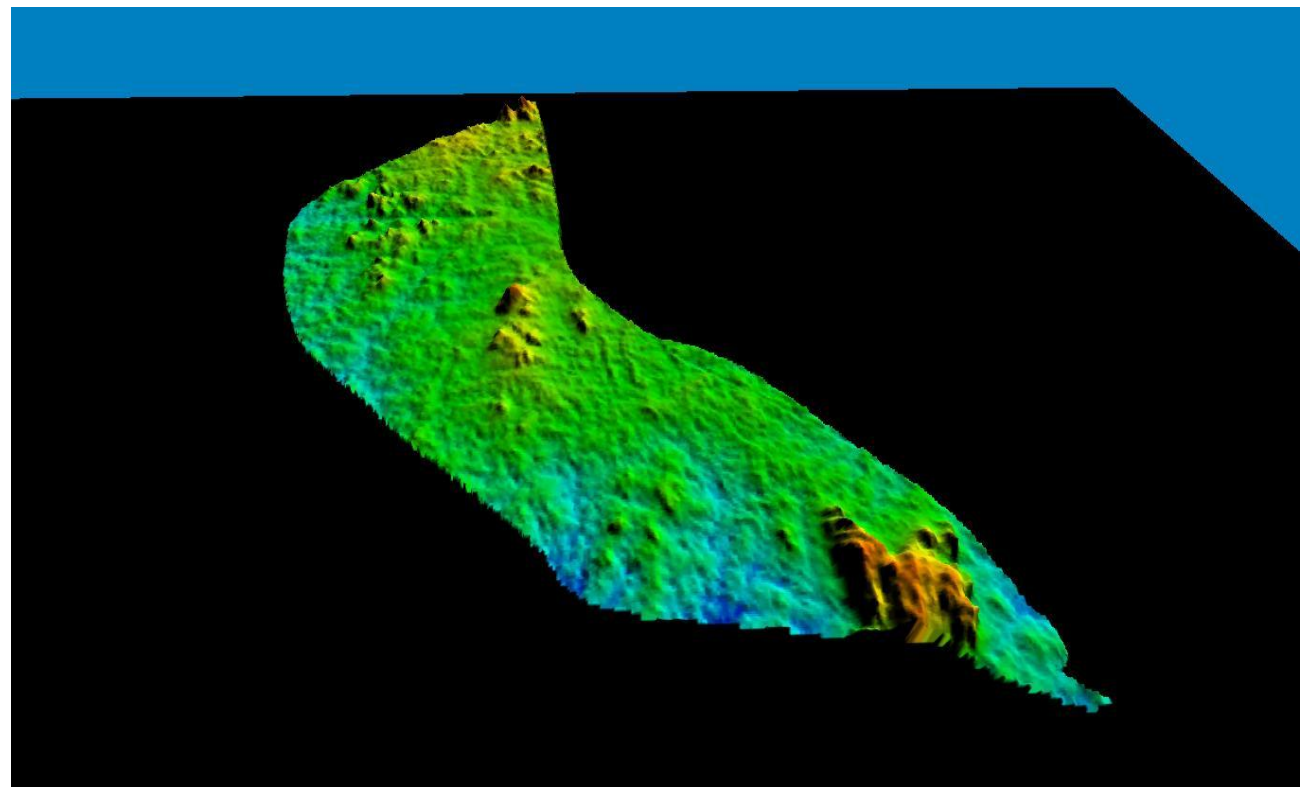

Figure 8: Digital Terrain Model of Akure.

\subsection{Geology/ Soil}

Sadek et al. (2001) emphasise that, in the selection of a site for municipal solid waste disposal / landfill, special care has to be given to the underlying foundation soil and bedrock characteristics: geologic structure, soil type, existing fractures, and so on. The aforementioned aspects affect the waste or leachate containment characteristics of a site. However, the geology of Akure is made of Precambrian basement making its geology and soil type suitable for landfill site selection. Figure 9 below shows the soil types of the study area. 


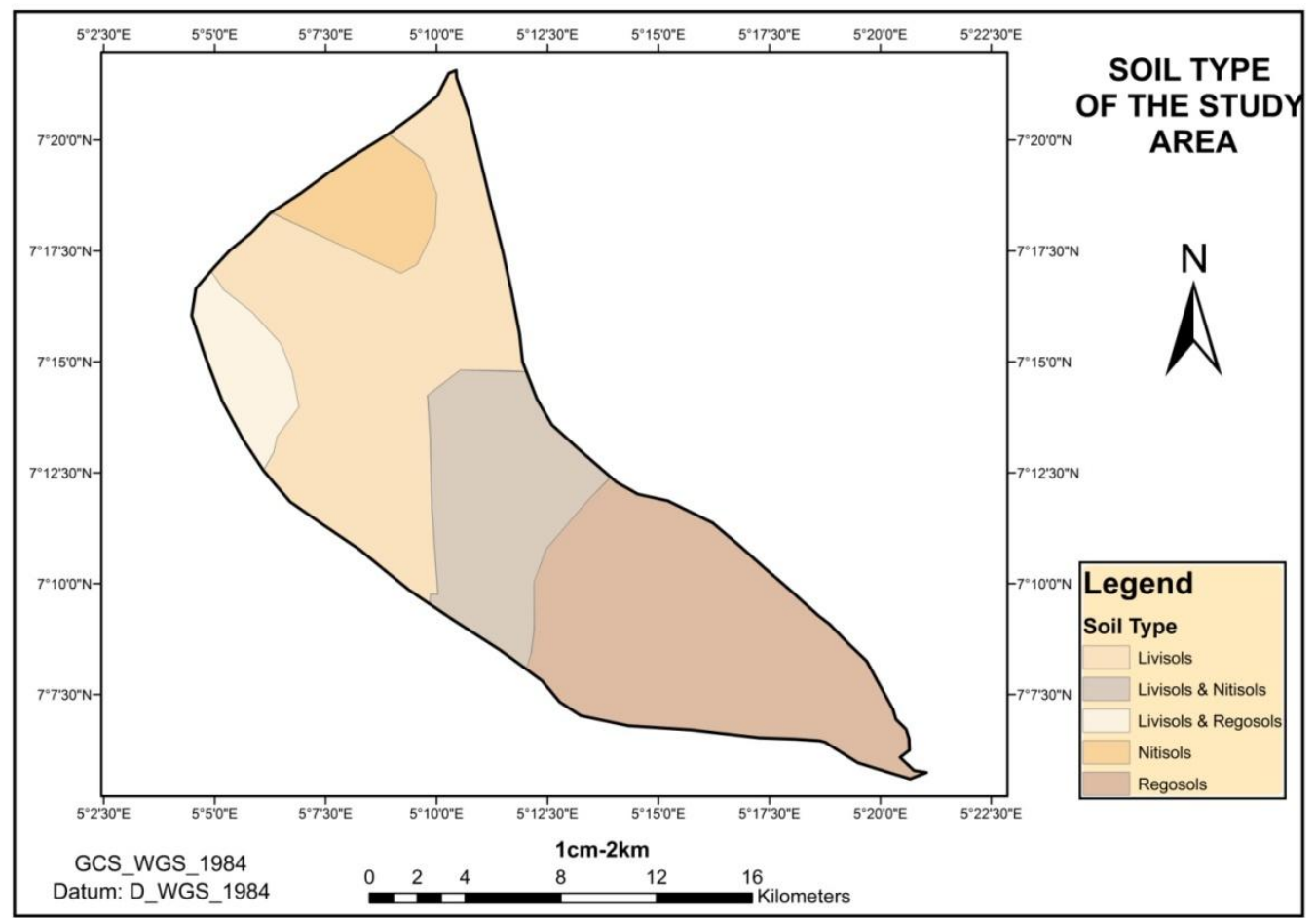

Figure 9: Soil types of Akure.

\subsection{Final Factor Map}

The final factor map was created using an overlay of all complete maps. The three factor maps which are slope, soil type and land use/land cover are overlaid on each other to produce the final factor map shown in figure 10 below

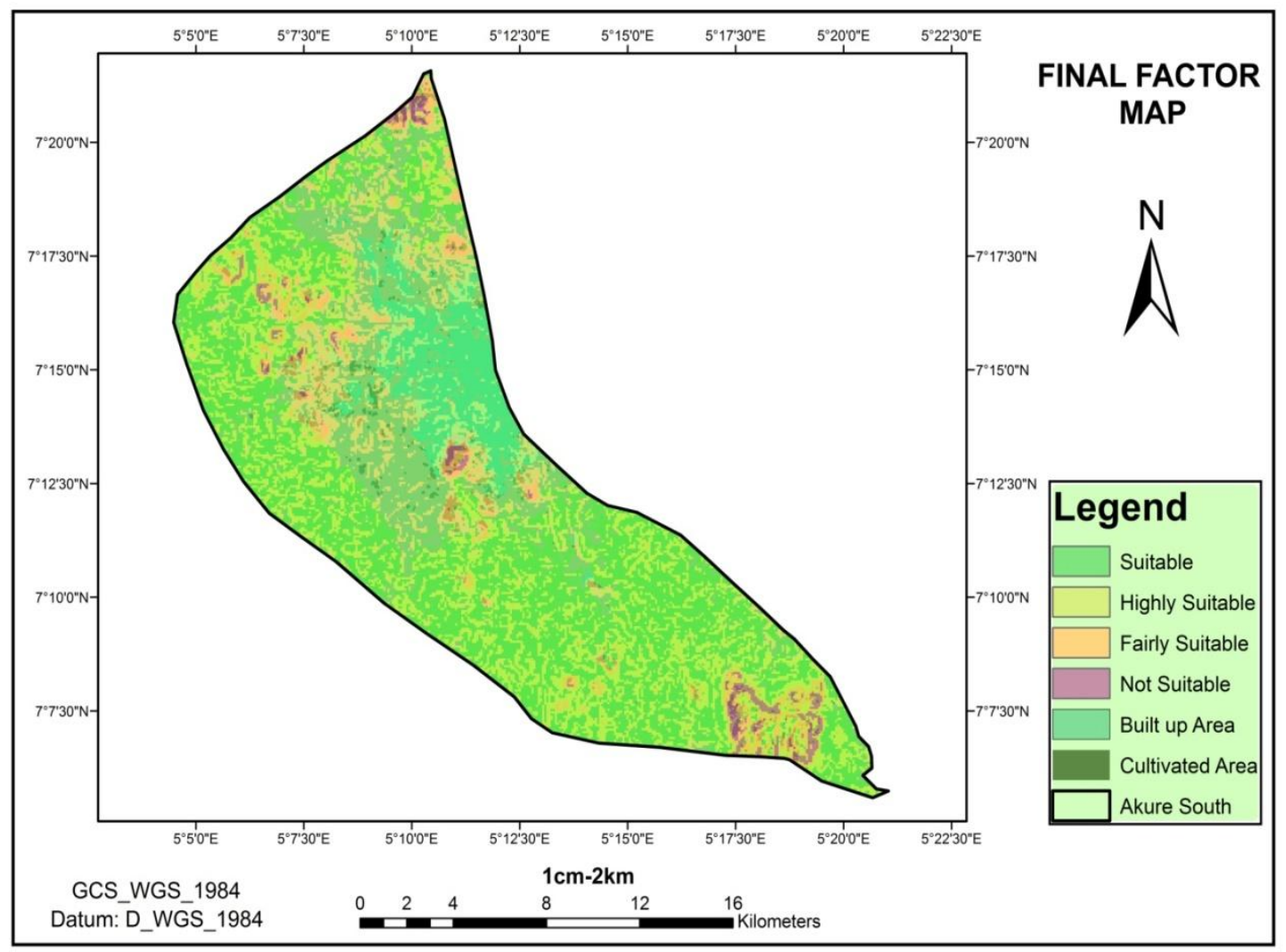

Figure 10: Final factor map showing Suitability of areas for Landfill in Akure 


\subsection{Proximity to major and minor roads}

Landfills should have suitable transport access, with power and water available. They should not be located within $100 \mathrm{~m}$ of any major highways, city streets or other transportation routes. The road constraint map is constructed in order to create a buffer zone around the major and minor roads in the study area. For this study, it is found that a buffer of 300 metres is sufficient for economic reasons, to avoid high transportation costs and mainly due to aesthetic reasons. Figure 11 below shows the buffered road network in the study area.

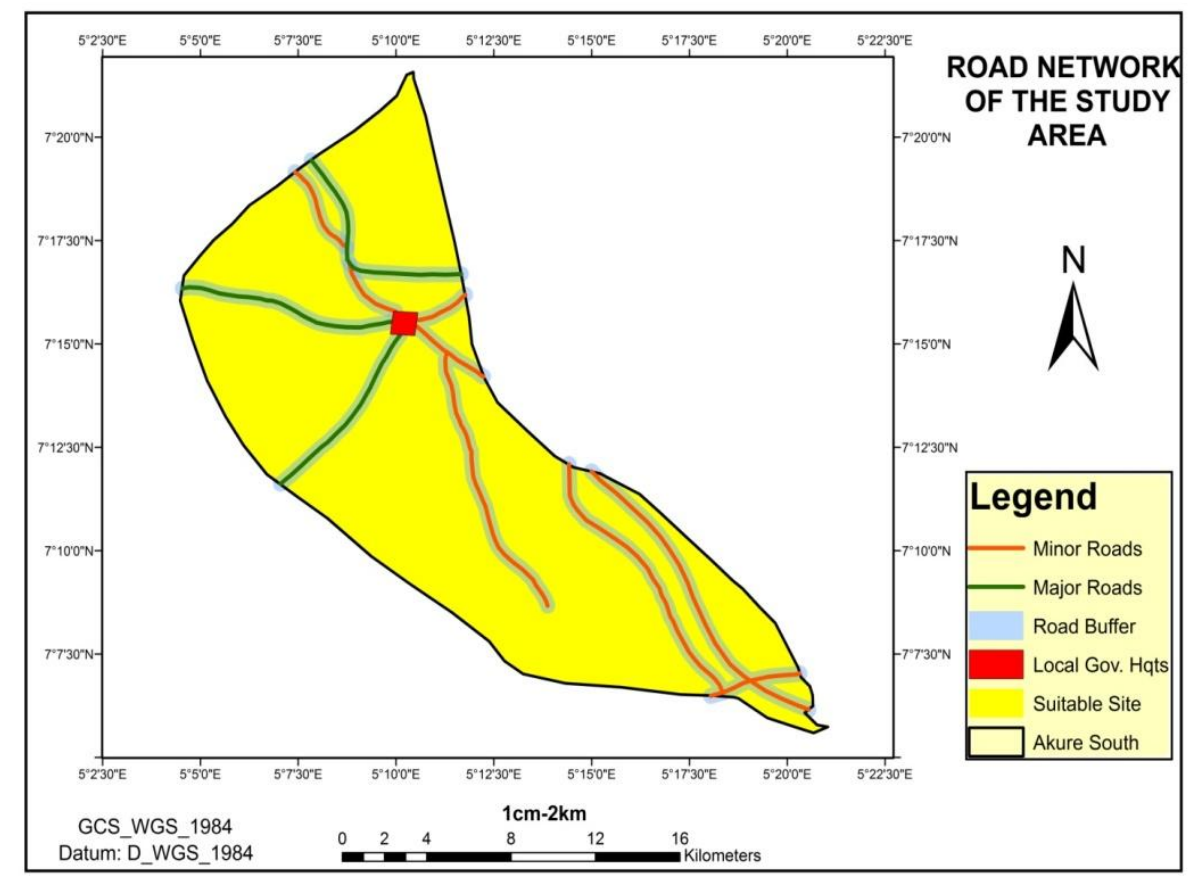

Figure 11: Buffered Road Map of Akure

\subsection{Proximity to Surface Water}

The surface water (rivers and streams) layer is constructed in order to create surface water constraint map with buffer zone around since they are not desirable region to build a landfill. This is due to the possibility of contaminants from a landfill leaching to the ground water and seeping into the rivers and streams. The constraint map (Figure 12) is then created using $750 \mathrm{~m}$ which is the minimum standard as buffer distances to minimize the risk of polluting water with leachate.

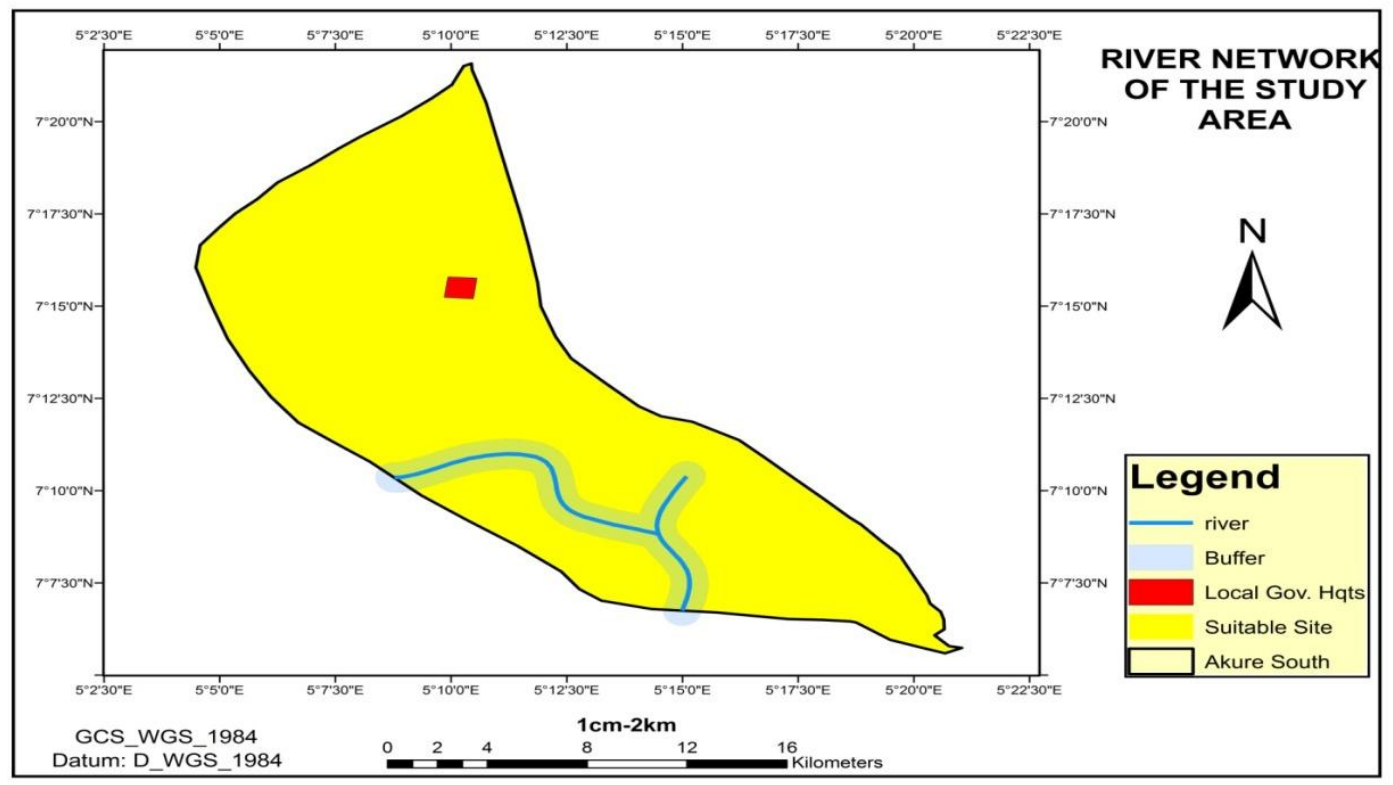

Figure 12: Surface Water Constraint Map of Akure 


\subsection{Final Constraint Map}

The constraint maps were produced by merging each individual theme within the study area. This procedure created a constraint map for each theme containing two major classes, suitable and not suitable sites. The two constraint map layers namely, rivers and roads network, were combined using overlay function to create a final map depicted below in Figure 13.

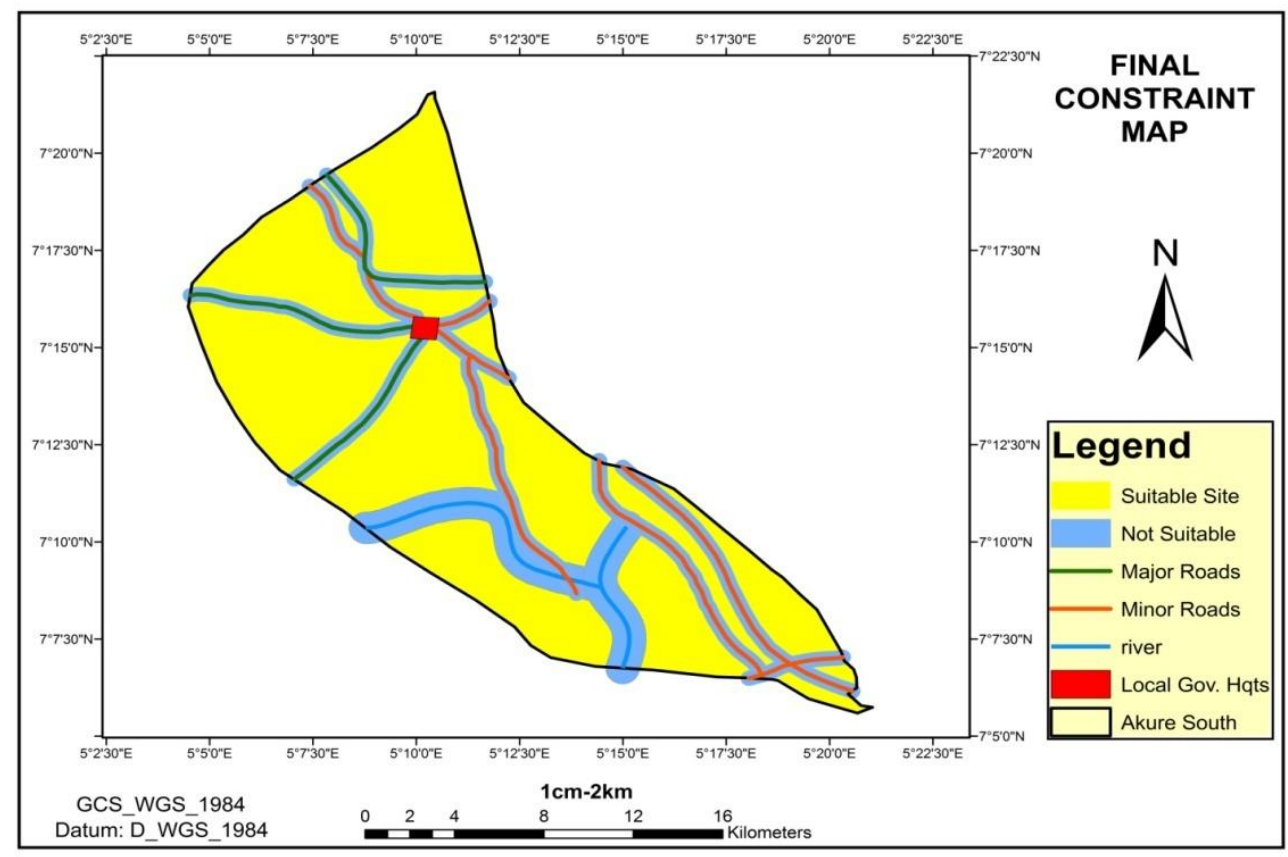

Figure 13: Final Constraint Map for Landfill Site in Akure.

\subsection{Final Suitability Map}

This approach consisted of the identification of locations that may present favourable conditions to the deposition of waste. The various maps analysed for environmental, socio and economic criteria were intersected to screen out unsuitable lands. Based on the available data, the final suitability map presented in Figure 14 was generated. The adopted criteria were applied to the spatial data using "If" or "Then" queries, buffering capabilities within GIS, and map overlays and intersections to create a composite site suitability map. The final factor map (Figure 13) and the final constraint map (Figure 10) were overlaid to produce a final suitability map as shown in figure 14 .

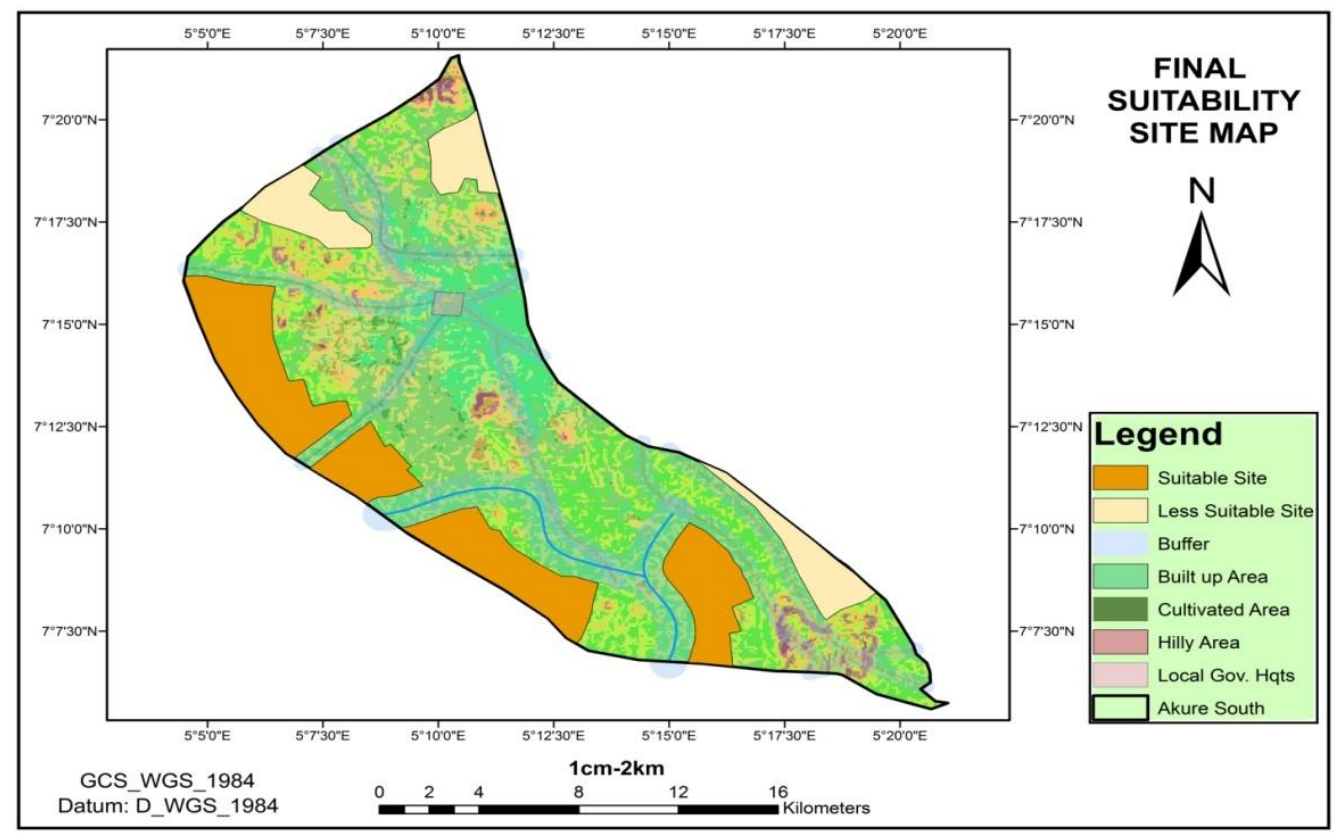

Figure 14: Final Suitability Map for Landfill Site in Akure 
The total area of all suitable sites is $58,907,035.76$ square metres which is the summation of the four (4) suitable landfill sites. The total area is therefore 5890.7 Hectares shown in figure 15 below.

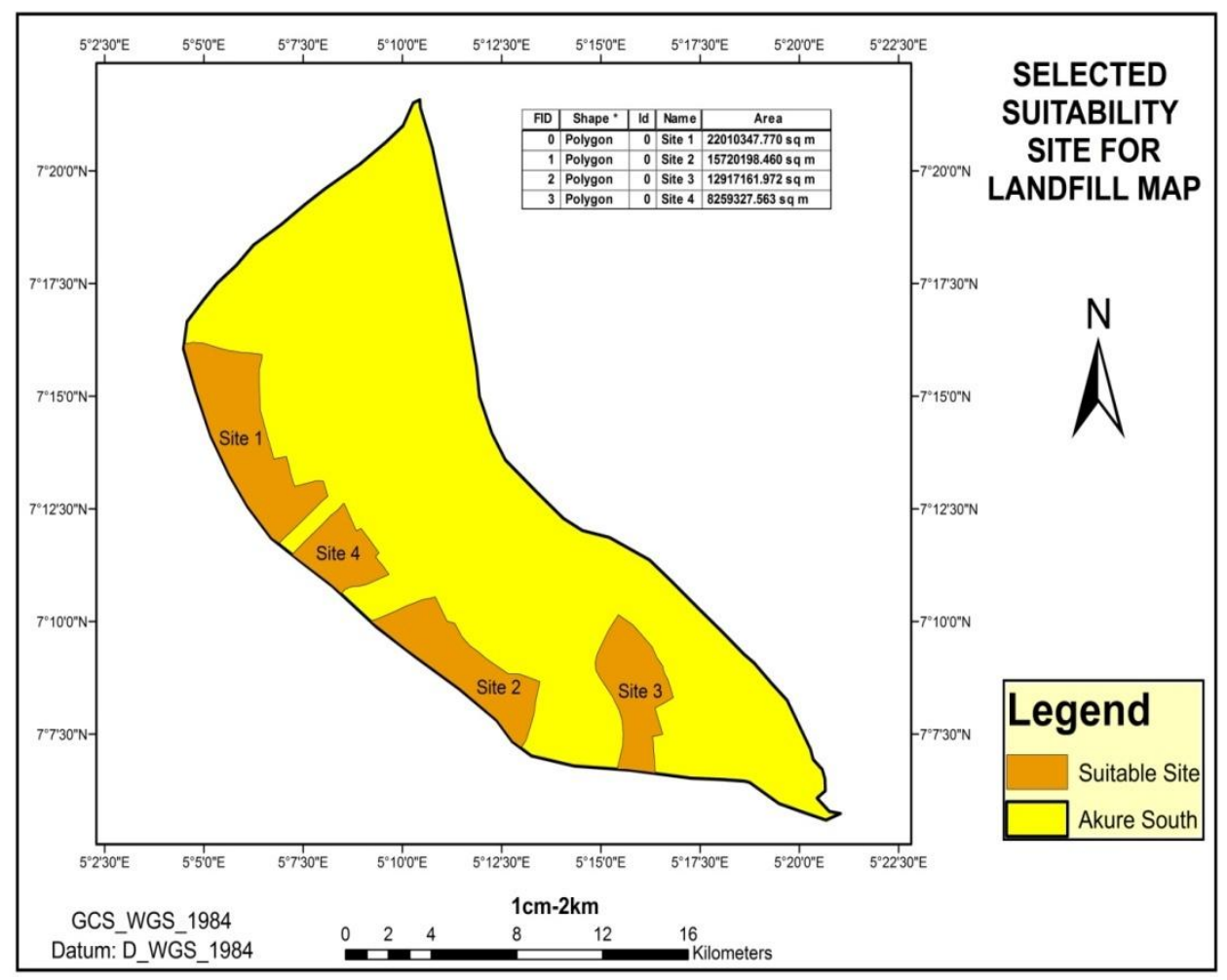

Figure 15: Final Suitable Landfill Sites in Akure

\section{Conclusion and Recommendations}

This study has highlighted the problems of waste disposal site in Akure, and its implications on the residents of the town. It has also identified high rate of waste generated as a critical issue in the study area. Akure is highly urbanized with big population and overcrowding. Waste is collected by the vehicles of Waste Management Authority on pre-arranged days while areas not serviced disposes their refuse either by burning, dumping on vacant plots, dumping in canals, gutters and dumping on the roadside. Over the years, people suffered from various afflictions and diseases arising from waste disposal problems.

The results of the GIS-based study showed that although suitable areas were limited, sufficient sites were chosen under predefined parameters. The sites are located and far from any environmental interest areas, streams, population clusters, which minimizes social conflict and environmental impacts. However, sites are located close enough to major and minor roads, which ensure that economic costs of implementation are minimal. The selected regions have slope less than $12 \%$, which have infrastructural advantage and a means of minimizing environmental impacts. The landfills selected are within six (6) kilometres and eighteen (18) kilometres to the city centre with a total area of 5890.7 Hectares mapped as suitable sites.

This study advances some recommendation as a way of ensuring functional waste management operations. The recommendations are both theoretical and practical approaches.

In the theoretical approach, citizen participation should be seen as an essential element in solid waste management. Significant improvement can be made in solid waste management if the public is made to participate actively in the planning and implementation of solid waste management. Raising public awareness and enlightenment programmes should be seen as one of the vital tools necessary for ensuring functional waste management operations. Government should encourage the private sector in the waste management in the city. GIS technology as a tool that aids facility siting process should be taught and used by both private and Government waste management agencies for sustainable siting of waste disposal sites.

\section{References}

[1]. Atkinson, S.F., Schoolmaster, F.A., Lyons, D.I. \& Coffey, J.M. (1995). A geographic information systems approach to sanitary landfill siting procedures: A case study. Environmental Professional. 17 (1): 20-26.

[2]. Basagoaglu, H., Celenk, E., Marino, M.A \& Usul, N. (1997). Selection of waste Disposal sites using GIS. Journal of the America Water Resources Association, 33(2): 455-463 
[3]. Bayode, T.J. (2011). Selection of water Disposal using GIS: A case study of Akure, Nigeria, B.Tech Thesis, Department of Urban and Regional Planning, Federal University of Technology, Akure, Nigeria.

[4]. Bloomfield, G.T (2000). Economic geography: A Handbook for GEOG*2230.

[5]. University of Guelph, Department of Geography. pp. 61-101

[6]. Bodhankar, N. \& Chatterjee, B. (1994). Pollution of limestone aquifer due to urban Waste disposal around Raipur, Madhya Pradesh, India. Environmental Geology, 23(1), 209-213.

[7]. Chakrabarti, S. (2003). Economics of solid waste management: A survey of existing Literature. Economic Research Unit Statistical Institute.Kolkata.

[8]. Dikshit, A.K ., Padmavathi, T. \& Das, R.K. (2000). Locating potential Landfill site Using Geographic Information System. Journal of Environmental Systems. 28(1): 43-54

[9]. Gao, S., Sundaram, D., and Paynter, J. (2004). Flexible Support for Spatial Decision-Making. Proceedings of the 37th Hawaii International Conference on System Sciences, 03(3): 30064a.

[10]. Kao, J., Chen, W., Lin, H. \& Guo, S. (1996). Network Expert Geographic Information System for landfill siting. Journal of Computing in Civil Engineering, 122(10): 307-317.

[11]. Kao, J. \& Lin, H. (1996). Multi-factor spatial analysis for landfill siting. Journal of Environmental Engineering, 122(10): 902-908

[12]. Nagar,B.B.\&.Mizra,U.K (2002). Hydro geology environmental assessment of Sanitary Landfill Project at jammu City, India. Electronic Green Journal. 17(8).

[13]. Sadek S., El-Fadel M. \& El-Hougeiri N. (2001). Optimizing Landfill Siting Through GIS Application, Seventeenth International Conference on Solid Waste Technology and Management, Philadelphia, October 21-24

[14]. Senthil S, (2002). GIS-MIS-GPS for solid waste management. In: Map India 2002.

[15]. Yagoub, M.M and Taher, B. (1998). GIS Application for Dumping Site Selection Proceedings of the $18^{\text {th }}$ Annual ESRI international Users Conference on Geographic Information System (GIS) Application, San Diego convention center, July 27-31. 